\title{
MEDIASI SEBAGAI SALAH SATU BENTUK PENYELESAIAN SENGKETA DI PENGADILAN AGAMA
}

\author{
Liliek Kamilah \\ Fakultas Hukum \\ Universitas Airlangga
}

\begin{abstract}
Abstraksi
Prosedur penyelesaian sengketa di pengadilan memakan waktu lama dan biaya tidak kecil, karena itu, mencari mekanisme penyelesaian cepat, yaitu melalui mediasi yang mengimplementasikan ke dalam hukum agama sebagaimana diatur dalam aturan Mahkamah Agung No. 1 tahun 2008 tentang prosedur mediasi di pengadilan

Kata kunci: Penyelesaian Sengketa, Mediasi Di Pengadilan

Abstract

The process of settlement of disputes in the courts take a long time and cost is not small, therefore, look for a quick resolution mechanisms, namely through the mediation that is implemented into the law docket of religion as stipulated in the Supreme Court rule No. 1 of 2008 on Mediation Procedure in court
\end{abstract}

Keywords: Dispute Resolution, Mediation, Court

\section{PENDAHULUAN}

Sebagai penyelenggara kekuasaan kehakiman, Pengadilan Agama mempunyai tugas pokok untuk membantu pencari keadilan dalam bentuk menerima, memeriksa, mengadili dan menyelesaikan perkara yang diajukan kepadanya, dengan berpegang teguh pada prinsip asas sederhana, cepat dan biaya ringan.

Semenjak berlakunya UndangUndang Nomor 3 Tahun 2006 tentang Perubahan atas Undang-Undang Nomor 7 Tahun 1989 mengenai Peradilan Agama, maka menjadikan kewenangan Pengadilan Agama semakin luas dan kompleks. Pasal 49 Undang-Undang Nomor 3 Tahun 2006 menyatakan bahwa
"Pengadilan Agama bertugas dan berwenang untuk memeriksa, memutus dan menyelesaikan perkara-perkara antara lain yang berhubungan dengan: (a)perkawinan; (b)waris; (c)wasiat; (d)hibah; (e)wakaf; (f) zakat; (g)infaq; (h)shadaqah; (i) ekonomi syari'ah.

Dalam penyelesaian sengketa tersebut tidak hanya dibatasi pada orangorang yang beragama Islam saja, namun juga orang atau badan hukum yang dengan sendirinya menundukkan diri dengan suka rela kepada hukum Islam. Dengan semakin banyaknya perkara yang ada dan seiring penambahan tugas serta kewenangan tersebut, tidak berarti mempengaruhi kinerja Pengadilan 
Agama dalam menangani perkara yang masuk. Pengadilan Agama tetap konsisten dengan asas yang melekat, yaitu asas sederhana, cepat dan biaya ringan dalam setiap penyelesaian sengketa atau perkara yang ada.

Salah satu bentuk dalam mewujudkan asas sederhana, cepat dan biaya ringan tersebut adalah dengan penerapan mediasi dalam penanganan perkara yang ada. Penerapan asas tersebut dalam bentuk mediasi ini juga sejalan dengan salah satu ayat yang ada dalam Kitab Suci Al-Qur'an Surat AlHujuraat ayat 10, yang artinya sebagai berikut: "Sesungguhnya orang-orang mukmin adalah saudara, karena itu damaikanlah antara kedua saudaramu dan bertakwalah kepada Allah supaya kamu mendapat rahmat"

Salah satu bentuk hasil dari Rakernas Mahkamah Agung Republik Indonesia yang diselenggarakan di Yogyakarta pada tanggal 24 sampai dengan tanggal 27 September 2001, telah mengisyaratkan tentang pemberdayaan Pengadilan tingkat pertama dalam menerapkan upaya perdamaian seperti yang diatur dalam Pasal 130 HIR/154 RBG dan pasal-pasal lainnya dalam hukum acara yang berlaku di Indonesia. Menurut ketentuan Pasal 130 ayat (1) HIR yang pada intinya berbunyi “Jika pada hari yang ditentukan, kedua belah pihak datang, maka Pengadilan Negeri dengan pertolongan ketua mencoba akan memperdamaikan mereka."

Bentuk pertolongan tersebut adalah dengan jalan mediasi yang diharapkan dapat menyelesaikan perkara sebelum proses persidangan berlangsung. Dengan keberhasilan mediasi, berarti kemudahan bagi pencari keadilan selama proses beracara di Pengadilan dapat dipastikan menjadi cepat terselesaikan dengan musyawarah di antara para pihak yang benar-benar sesuai dengan keinginan kedua belah pihak. Bentuk penyelesaian yang demikian ini cukup efektif dan seharusnya tetap dipertahankan dalam masyarakat. Hal ini mengingat basis sosiokultural yang cukup melekat dalam masyarakat Indonesia dalam mengambil keputusan secara musyawarah langsung di antara mereka yang bersengketa.

Mengingat bunyi konsideran Peraturan Mahkamah Agung RI Nomor 2 Tahun 2003 di cabut dengan PERMA no 1 tahun 2008 tentang Prosedur Mediasi di Pengadilan, ditegaskan bahwa pengintegrasian mediasi ke dalam proses beracara di Pengadilan, dapat menjadi salah satu instrumen efektif dalam mengatasi kemungkinan penumpukan perkara di Pengadilan. Embrio lahirnya PERMARI Nomor 2 
Tahun 2003 di cabut dengan PERMA no 1 tahun 2008 ini dikarenakan jumlah tumpukan atau tunggakan perkara di MA, sehingga mendorong ketua MA pada saat itu (Bagir Manan) untuk menetapkan mediasi sebagai salah satu cara mengurangi perkara di Lembaga Peradilan, khususnya di Mahkamah Agung.

Adapun alasan yang melatarbelakangi penerapan mediasi dalam penyelesaian sengketa menurut Hasnawaty Abdullah dalam tulisannya yang berjudul "Penerapan Mediasi di dalam Praktek Peradilan", antara lain adalah sebagai berikut: (1)Perlunya tata cara penyelesaian sengketa yang fleksibel dan responsif bagi para pihak yang bersengketa; (2)Menumbuhkan keterlibatan masyarakat dalam penyelesaian sengketa; (3)Memperluas akses mencapai atau mewujudkan keadilan sehingga setiap sengketa yang memiliki ciri-ciri tersendiri terkadang tidak sesuai dengan bentuk penyelesaian yang satu cocok dengan bentuk penyelesaian yang lain, untuk itu para pihak dapat memilih mekanisme penyelesaian sengketa yang terbaik dan sesuai dengan situasi atau sengketa yang dipersengketakan. (Takdir Rakhmadi, 1996;12)

Karena perbedaan pandangan tidaklah mustahil bila terjadi perbedaan pelaksanaan mediasi yang disebabkan oleh karena mereka tetap pada pendiriannya. Sehingga harapan pelaksanaan mediasi yang diharapkan dapat mengurangi penumpukan perkara menjadi tidak berhasil. Dalam kondisi yang demikian ini, otomatis akan membebani dan merugikan para pihak yang berperkara. Dengan demikian berlanjutnya perkara di Pengadilan akan membuat asas sederhana, cepat dan biaya ringan tidak dapat dicapai.

Walaupun demikian, usaha untuk mewujudkan keinginan yang diharapkan semua Pengadilan Agama selaku lembaga penyelenggara kekuasaan kehakiman, akan tetap mengutamakan mediasi tidak hanya formalitas saja. Tetapi benar-benar dilaksanakan dengan konsisten terhadap setiap perkara yang membutuhkan keadilan.

Adapun permasalahan yang akan dikaji secara lebih lanjut dalam tulisan ini adalah mengenai: (1)Penerapan mediasi dalam membantu penyelesaian sengketa atau perkara di Pengadilan Agama; (2)Upaya hukum terhadap putusan mediasi yang tidak ditaati; (3)Kesiapan Peradilan Agama melaksanakan ketentuan Undang-Undang No. 3 tahun 2006 tentang perubahan kewenangan Peradilan Agama.

\section{Penerapan Mediasi Dalam Membantu} Penyelesaian Sengketa di Pengadilan Agama

Proses pencarian keadilan melalui lembaga Pengadilan tidaklah mudah, 
karena mungkin saja memerlukan waktu yang lama dan biaya yang tidak sedikit. Padahal tidak dapat dipungkiri bahwa tidak semua para pencari keadilan ataupun para pihak yang berperkara memiliki banyak waktu dan keuangan yang mencukupi. Selain kendala tersebut, tidak jarang terjadi penumpukan perkara di Pengadilan yang mengakibatkan proses berperkara menjadi lama dan memerlukan biaya yang tidak sedikit. Oleh karena itu perlu kiranya dicari suatu jalan keluar agar dapat mempermudah para pencari keadilan atau para pihak yang berperkara melalui sebuah mekanisme yang lebih fleksibel daripada proses beracara di Pengadilan.

Untuk memenuhi tuntutan tersebut juga untuk menghindari penumpukan perkara, maka sesuai SEMA Nomor 1 Tahun 2002 tentang Pemberdayaan Pengadilan Tingkat Pertama Menerapkan Lembaga Damai (Eks Pasal 130 HIR/154 $\mathrm{RBg}$ ) dan Kesimpulan Hasil Diskusi Komisi II Rakernas Terbatas MA RI tentang Pelaksanaan Upaya Perdamaian menurut Pasal 130 HIR/154 RBg tanggal 26 dan 27 September 2002 di Surabaya, yang mengisyaratkan adanya suatu mekanisme baru dalam dunia peradilan, yaitu adanya lembaga damai, yang pada intinya adalah sebagai berikut: (1)Bahwa upaya perdamaian hendaklah dilakukan dengan sungguh-sungguh dan optimal, tidak sekedar formalitas; (2)Melibatkan hakim yang ditunjuk dan dapat bertindak sebagai fasilitator dan atau mediator, tetapi bukan hakim majelis (namun hasil Rakernas memperbolehkan dari hakim majelis dengan alasan kurangnya tenaga hakim di daerah dan karena lebih mengetahui permasalahan), atau para pihak yang bersangkutan meminta pihak lain (ketiga) yang dianggap mampu kepada Ketua Majelis; (3)Apabila upaya damai ini membutuhkan waktu lama, maka pemeriksaan perkara dapat melampaui waktu maksimal 6 (enam) bulan sebagaimana diatur dalam SEMA Nomor 6 Tahun 1992; (4) Persetujuan perdamaian dibuat dalam bentuk Akta Perdamaian (Dading), dan para pihak dihukum untuk mentaati apa yang telah disepakati; (5)Apabila tidak berhasil, hakim yang bersangkutan harus melaporkan kepada Ketua Pengadilan/ Ketua Majelis dan pemeriksaan perkara dilanjutkan; (6) Fasilitator/mediator harus netral dan imparsial, tidak boleh terpengaruh secara internal maupun eksternal, tidak berperan sebagai hakim yang menentukan salah atau benar, bukan sebagai penasehat; (7)Keberhasilan penyelesaian perkara melalui perdamaian, dapat dijadikan bahan penilaian (reward) bagi hakim yang menjadi fasilitator/ mediator. (Nashrudin Salim, 2004;^)

Dengan berdasarkan pada hal-hal 
tersebut di atas, maka kemudian Mahkamah Agung mengeluarkan PERMA Nomor 2 Tahun 2003 di cabut dengan PERMA no 1 tahun 2008 tentang Prosedur Mediasi di Pengadilan, dengan alasan: (1)Mengurangi masalah penumpukan perkara; (2)Proses penyelesai an sengketa lebih cepat dan murah; (3)Penyempurnaan SEMA Nomor 1 Tahun 2002 tentang Pemberdayaan Pengadilan Tingkat Pertama Menerapkan Lembaga Damai (Eks Pasal 130 HIR/154 $\mathrm{RBg}$ ); (4)Institusionalisasi proses mediasi ke dalam sistem peradilan; (5)Mendorong para pihak untuk menempuh proses perdamaian yang dapat diintensifkan dengan cara mengintegrasikan proses mediasi ke dalam prosedur berperkara di Pengadilan Negeri; (6)Mengisi kekosongan hukum.

Mediasi menurut Pasal 1 ayat (7) PERMA di cabut dengan PERMA no 1 tahun 2008 adalah "penyelesaian sengketa melalui proses perundingan para pihak dengan dibantu oleh mediator. Disini akan tergambar bahwa dalam mediasi terdiri atas 3 (tiga) subyek yaitu, para pihak (2 subyek) dan mediator. Ketiga subyek tersebut berusaha menyelesaikan obyek atau sengketa yang dihadapi oleh para pihak.

Mediasi ini diharapkan dapat dilaksanakan secara maksimal bukan hanya sekedar formalitas, sehingga apa yang diharapkan para pencari keadilan atau para pihak yang berperkara untuk memperoleh keadilan dapat terwujud. Sesungguhnya ada dua keuntungan yang didapatkan apabila para pihak yang berperkara memilih penyelesaian sengketa mereka dilakukan dengan jalan mediasi, yaitu sebagai berikut: (1)Ada dua asas penting dalam mediasi, yaitu yang pertama menghindari kalah menang, melainkan sama-sama menang. Asas kedua, putusan tidak mengutamakan pertimbangan dan alasan hukum, melainkan atas dasar kesejajaran, kepatutan dan rasa keadilan; (2)Penyelesaian melalui mediasi, mempersingkat waktu penyelesaian dibandingkan berperkara. (Marni Emmy Mustafa, 2007;24)

Dalam konsideran PERMA Nomor 2 Tahun 2003 huruf e dijelaskan bahwa "Hukum acara yang berlaku baik Pasal 130 HIR maupun Pasal 154 RBg, mendorong para pihak untuk menempuh proses perdamaian yang diintensifkan dengan cara mengintegrasikan proses mediasi ke dalam prosedur berperkara di pengadilan tingkat pertama." Kemudian dalam Pasal 2 PERMA Nomor 2 Tahun 2003 juga menyatakan bahwa, "Semua perkara perdata yang diajukan ke pengadilan tingkat pertama wajib untuk 
lebih dahulu diselesaikan melalui perdamaian dengan bantuan mediasi." Dalam Pasal 16 PERMA Nomor 2 Tahun 2003 disebutkan bahwa "Apabila dipandang perlu ketentuan-ketentuan dalam PERMA ini, selain dipergunakan dalam lingkungan badan peradilan umum dapat juga diterapkan dalam lingkungan badan peradilan lainnya."

Dari ketentuan tersebut, maka kiranya dapat disimpulkan bahwa proses mediasi juga dapat diterapkan di Pengadilan Agama. Selain mengandung banyak keuntungan dan manfaat, proses mediasi juga merupakan salah satu proses agar perkara dapat lebih cepat diselesaikan dengan biaya ringan. Selain itu dengan mediasi, dapat memberikan akses kepada para pihak yang bersengketa untuk memperoleh keadilan atau penyelesaian sengketa yang memuaskan. Hal ini sejalan dengan apa yang dikemukakan oleh ketua Mahkamah Agung, Bagir Manan, bahwa Pengadilan Agama telah pula diperkenalkan mediasi untuk lebih merukunkan kembali keluarga yang sedang retak (ingin bercerai).

Adapun perkara-perkara yang dapat diselesaikan dengan menggunakan prosedur mediasi adalah perkara contentius, yaitu suatu perkara yang di dalamnya berhadapan dua belah pihak yang bersengketa. Sedangkan perkara voluntair atau perkara yang bersifat permohonan dan di dalamnya tidak ada sengketa, sehingga tidak ada lawan, maka secara umum perkara semacam ini tidak memerlukan mediator untuk melakukan mediasi.

Selanjutnya perkara di Pengadilan Agama yang dapat diselesaikan dengan proses mediasi antara lain dapat dijelaskan sebagai berikut: (a)Mediasi perkara perceraian, Dalam perkara perceraian di Pengadilan Agama, upaya damai ini diatur dalam Pasal 65, Pasal 70 ayat (1), Pasal 82 dan Pasal 83 Undang-Undang Nomor 7 Tahun 1989 yang telah diubah dengan Undang-Undang Nomor 3 Tahun 2006, kemudian juga diatur dalam Pasal 39 ayat (1) Undang-Undang Nomor 1 Tahun 1974 tentang Perkawinan, dalam Pasal 31 dan 32 Peraturan Pemerintah Nomor 9 Tahun 1975, serta dalam Pasal 115 Kompilasi Hukum Islam.

Prosedur mediasi dalam penyelesaian perkara perceraian di Pengadilan Agama adalah dengan berpedoman pada PERMARI Nomor 2 Tahun 2003. Pada hari pertama proses persidangan, hakim wajib mengupayakan agar para pihak damai dan rukun kembali. Apabila dalam sidang pertama tersebut, kedua belah pihak samasama menunjukkan sikap tidak bisa untuk hidup rukun kembali, maka perkara 
perceraian tersebut tidak perlu diproses melalui mediasi. Namun upaya mendamaikan kedua pihak yang berperkara harus tetap dilakukan oleh Majelis Hakim yang memeriksa perkara tersebut, sebelum perkara tersebut diputus. Usaha perdamaian oleh Majelis Hakim ini dapat dilakukan dalam setiap persidangan.

Sedangkan apabila dalam sidang pertama, pihak tergugat atau termohon masih menunjukkan sikap atau keinginan untuk dapat hidup rukun kembali, maka Majelis Hakim seketika itu, memberikan penjelasan kepada para pihak, untuk terlebih dahulu menempuh jalur mediasi dengan menunjuk mediator dari kalangan hakim Pengadilan Agama, namun bukan hakim yang memeriksa perkara tersebut. Hal ini dikarenakan hakim yang memeriksa perkara tersebut, dilarang bertindak sebagai mediator bagi perkara yang bersangkutan.

Setelah penunjukan mediator, persidangan perkara tersebut ditunda selama satu bulan untuk memberikan kesempatan kepada para pihak menjalani proses mediasi. Pada saat yang sama, Majelis Hakim juga menentukan hari dan tanggal persidangan yang akan datang. Apabila dalam proses mediasi tersebut berhasil dicapai kesepakatan untuk damai atau rukun kembali, maka pada hari dan tanggal sidang yang telah ditetapkan sebelumnya, para pihak wajib menghadap persidangan, untuk memberitahukan bahwa telah dicapai kesepakatan damai atau rukun kembali. Dengan telah dicapainya kesepakatan damai, maka perkara perceraian tersebut harus dicabut. Terhadap ketentuan ini tidak perlu dibuat suatu akta perdamaian, karena apabila perjanjian yang telah disepakati oleh para pihak ini dilanggar oleh salah satu pihak, maka akta perdamaian itu tidak dapat dieksekusi, karena akibat dari perbuatan tersebut tidak lalu mengakibatkan putusnya perkawinan.

Selanjutnya apabila proses mediasi tersebut tidak menghasilkan suatu kesepakatan damai, maka kedua belah pihak wajib menghadap persidangan pada hari dan tanggal yang telah ditetapkan Majelis Hakim, dan mediator berkewajiban memberitahukan kepada Majelis Hakim bahwa proses mediasi telah gagal atau tidak berhasil. Kemudian setelah Majelis Hakim menerima pemberitahuan tersebut, maka Majelis Hakim segera melanjutkan pemeriksaan perkara sesuai dengan ketentuan hukum acara yang berlaku.

Mediasi, tidak hanya dapat diterapkan dalam perkara perceraian semata, namun dapat pula diterapkan dalam perkara-perkara di Pengadilan Agama selain perkara perceraian. Prosedur mediasinya pun pada dasarnya 
sama. Majelis Hakim dalam persidangan pertama menganjurkan kepada para pihak yang berperkara untuk terlebih dahulu menempuh proses mediasi. Hanya saja dalam perkara selain perceraian ini, apabila dari proses mediasi tersebut dicapai suatu kesepakatan, maka para pihak yang berperkara dengan dibantu mediator wajib merumuskan kesepakatan tersebut secara tertulis. Hasil kesepakatan tersebut kemudian ditandatangani oleh kedua belah pihak, setelah sebelumnya mediator memeriksa materi kesepakatan, untuk menghindari adanya kesepakatan yang bertentangan dengan hukum.

Pada hari dan tanggal yang telah ditetapkan oleh Majelis Hakim, kedua belah pihak yang berperkara wajib menghadap persidangan tersebut, untuk memberitahukan bahwa telah tercapai suatu kesepakatan dalam proses mediasi. Kemudian hakim akan menjatuhkan putusan perdamaian dengan menghukum para pihak tersebut untuk mentaati dan melaksanakan isi perdamaian. Ketika proses mediasi tidak menghasilkan suatu kesepakatan, maka prosesnya sama dengan proses mediasi dalam perkara perceraian sebagaimana telah diuraikan sebelumnya. Selanjutnya Majelis Hakim akan melanjutkan pemeriksaan perkara tersebut sesuai dengan hukum acara yang berlaku.

\section{Upaya Hukum Terhadap Putusan Mediasi yang Tidak Ditaati}

Hasil dari proses mediasi merupakan cerminan keinginan sesungguhnya dari kedua belah pihak atas penyelesaian perkara di antara mereka. Hasil mediasi yang tertuang dalam akta perdamaian tentunya mempunyai kekuatan hukum tetap (inkracht van gewijsde) yang wajib ditaati dan dilaksanakan oleh kedua belah pihak. Namun pada kenyataannya, tidak semua pihak yang berperkara tersebut, bersedia mentaati dan melaksanakan isi putusan dengan berbagai alasan.

Putusan mediasi mempunyai beberapa akibat hukum, yaitu sebagai berikut: (1) Mempunyai kekuatan hukum tetap (inkracht van gewijsde) seperti halnya putusan pengadilan dalam tingkat penghabisan; (2)Tertutup upaya banding dan kasasi, yang berarti bahwa sejak ditetapkan atau dijatuhkan oleh hakim, maka putusan perdamaian tersebut telah melekat, pasti dan tidak ada penafsiran lagi. Ini berarti putusan perdamaian tersebut langsung dapat dijalankan kapan pun diminta oleh pihak-pihak yang melaksanakan perdamaian itu; (3)Memiliki kekuatan eksekutorial, yang berarti putusan 
tersebut langsung dapat dieksekusi, apabila ternyata ada salah satu pihak yang tidak mau melaksanakan dan mentaati putusan damai tersebut.

Adapun eksekusi yang dimintakan kepada pengadilan terhadap pihak yang telah menyimpangi putusan mediasi ini antara lain berupa; (a)Jika putusan perdamaian itu mengandung eksekusi riil, maka berlaku sepenuhnya ketentuan yang tersebut dalam Pasal 200 HIR ayat (11) dan Pasal 1033 Rv; (b)Jika putusan perdamaian itu menyangkut eksekusi pembayaran sejumlah uang, maka berlaku ketentuan sebagaimana yang diatur dalam Pasal 195 sampai dengan Pasal 200 HIR. (c)Jika eksekusi mengandung pelaksanaan suatu perbuatan, maka berlaku sepenuhnya ketentuan eksekusi yang diatur dalam Pasal 225 HIR.

Penerapan eksekusi terhadap putusan mediasi yang tidak ditaati dalam lingkup Pengadilan Agama, dalam perkara perceraian misalnya, apabila berhasil dicapai suatu kesepakatan damai, maka gugatan perceraian yang diajukan ke pengadilan oleh para pihak, dengan sendirinya harus dicabut. Seperti telah diuraikan sebelumnya, dalam putusan damai perkara perceraian ini, tidak dibuat suatu akta perdamaian. Sehingga apabila ada salah satu pihak yang melanggar, maka akta perdamaian itu tidak dapat dieksekusi, karena akibat dari perbuatan tersebut tidak mengakibatkan putusnya perkawinan. Selanjutnya satu-satunya upaya hukum yang dapat digunakan oleh para pihak yang merasa dirugikan dengan putusan perdamaian dalam lingkup Pengadilan Agama, adalah dengan mengajukan perlawanan ke pengadilan dalam bentuk derden verzet atau partai verzet. Dalam derden verzet, yang menjadi objek putusan perdamaian tersebut, bukan milik para pihak yang membuat persetujuan perdamaian itu, tetapi milik orang lain atau dengan alasan bahwa barang itu telah diagunkan kepada pihak lain atau barang itu telah diletakkan padanya sita eksekusi untuk kepentingan pelawan (conservatoir beslag).

Sedangkan untuk partai verzet sendiri, dapat dilakukan dengan alasan adanya cacat formal atau cacat material yang melekat pada putusan perdamaian tersebut. Hal tersebut terjadi apabila isi putusan perdamaian itu tidak berdasarkan kesepakatan bersama, atau tidak mengakhiri keseluruhan dari sengketa, karena masih ada hal-hal lain yang tidak diselesaikan. Selain itu dapat pula disebabkan karena isi putusan perdamaian yang ternyata menyimpang dari kesepakatan, atau karena putusan perdamaian itu telah dilaksanakan secara sukarela, atau karena pemintaan eksekusi yang masih prematur. 
Kesiapan Peradilan Agama Melaksanakan

Ketentuan Undang Undang Nomor 3

Tahun 2006 Tentang Perubahan

Kewenangan Peradilan Agama

Sebagai wujud dari dinamika perkembangan kewenangan Peradilan Agama seperti yang tertuang dalam pasal 49 Undang-Undang No. 3 tahun 2006, telah memberikan perluasan kewenangan yang ditandai dengan masuknya perkara ekonomi syariah dalam lingkup kewenangan Peradilan Agama. Mengingat perkembangan ekonomi syariah di Indonesia begitu pesat, khususnya bidang perbankan, asuransi, dan pasar modal dan lainlainnya yang berdasar syariah, maka tidak mustahil apabila pemerintah, masyarakat serta para praktisi ekonomi syariah memerlukan fatwa-fatwa hukum syariah yang tepat dan akurat yang berkaitan dengan produk dan praktik di lembaga-lembaga keuangan syariah yang memiliki landasan syariah yang kuat. Untuk itu maka pada tahun 1999 dibentuklah Dewan Syariah Nasional (DSN) sebagai bagian dari MUI. (www.google.com)

Fatwa DSN dalam bidang ekonomi syariah ini, tidak hanya mengikat bagi praktisi ekonomi syariah, tetapi juga bagi masyarakat Islam Indonesia dan masyarakat lain yang tunduk terhadap syariat Islam selaku subyek hukum ekonomi syariah. Mengingat lingkup ekonomi syariah masuk bidang hukum perdata (muamalah) sehingga jika timbul sengketa dalam bidang tersebut maka dibutuhkan penyelesaian berdasarkan ketentuan ekonomi syariah atau melalui proses arbitrase berdasarkan ketentuan Undang-Undang No. 30 tahun 1999 tentang arbitrase dan pilihan penyelesaian sengeketa.

Dalam hal penyelesaian sengketa ekonomi syariah di luar lembaga peradilan maka ada Basyarnas (Badan Arbitrase Syariah Nasional) yang berwenang mengambil alih tugas untuk menyelesaikan sengketa muamalah yang dihadapi oleh orang-orang Islam di Indonesia. Selama dalam proses pemeriksaan selalu diupayakan perdamaian serta musyawarah sedangkan pada prinsipnya musyawarah dan perdamaian merupakan keinginan setiap orang. Dalam syariah keberadaan perdamaian itu sangat dianjurkan karena dengan perdamaian semua orang akan terhindar dari kehancuran silaturahmi sekaligus terhindar dari permusuhan terutama bagi para pihak yang bersengketa tersebut dapat mengakhiri sengketa yang dihadapi dengan cara yang baik tanpa menimbulkan masalah baru diantara kedua belah pihak, sehingga para pihak merasa sama-sama puas karena tidak ada pihak 
yang merasa kepentingannya dirugikan dan dikalahkan.

Dengan demikian penyelesaian sengketa melalui arbitrase yang ditangani Basyarnas tidak bertentangan dengan prinsip syariah.

Perlu diketahui masyarakat bahwa sebelum Basyarnas ini ada, telah ada Badan Arbitrase Muamalah Indonesia (BAMUI) yang tugasnya untuk menyelesaikan kemungkinan terjadinya sengketa muamalat yang timbul dalam lingkup perdagangan, industri, keuangan, jasa dan lain-lain di kalangan umat Islam. (Ahmad Dimyati, 1994;192)

Untuk sengketa yang terdaftar pada Basyarnas, maka proses penyelesaiannya menggunakan prosedur Basyarnas sehingga Pengadilan Negeri tidak dapat mengadili sengketa yang terikat dengan perjanjian arbitrase, kecuali hanya berwenang untuk melakukan eksekusi terhadap jaminan. Berdasarkan pasal 60 Undang-Undang No. 30 tahun 1999, putusan arbitrase (termasuk Basyarnas) bersifat final dan mengikat para pihak serta mempunyai kekuatan hukum tetap.

Penyelesaian sengketa melalui lembaga arbitrase hanya dapat dilakukan apabila kedua belah pihak yang bersengketa sama-sama sepakat untuk menyelesaikan perkara tersebut dengan perantara lembaga arbitrase dengan ketentuan bahwa kesepakatan tersebut telah dicantumkan dalam suatu perjanjian yang dibuat terlebih dahulu sebelum sengketa itu terjadi yang dimuat dalam suatu akta khusus. Apabila salah satu pihak ataupun kedua belah pihak tidak bersepakat untuk menyelesaikan sengketa dengan bantuan lembaga arbitrase maka jalur yang dapat ditempuh adalah melalui jalur litigasi yaitu dengan mengajukan gugatan melalui Pengadilan Negeri yang merupakan pengadilan di tingkat pertama di lingkungan Pengadilan umum, sesuai dengan ketentuan pasal 50 UndangUndang No. 2 tahun 1986 yang diubah dengan Undang-Undang No. 8 tahun 2004 tentang Pengadilan Umum. Dari ketentuan tersebut dapat dikatakan bahwa perkara-perkara ekonomi yang merupakan perkara perdata dalam lingkup ekonomi syariah di dalamnya, merupakan kewenangan absolut dari Pengadilan Umum/Negeri.

Dengan lahirnya UndangUndang No. 3 tahun 2006 menimbulkan konsekwensi hukum bahwa Pengadilan Negeri kehilangan kewenangan dalam menangani perkara ekonomi syariah. Hal ini merupakan dampak yang timbul dari perluasan kewenangan Pengadilan Agama sebagaimana dicantumkan 
dalam pasal 49 Undang-Undang No. 3 tahun 2006. Walaupun ini merupakan tantangan dan tugas yang cukup berat, akan tetapi sekaligus membawa rahmat tersendiri sebab banyak pihak seperti perbankan, perguruan tinggi, organisasi yang bergerak di bidang ekonomi syariah dan masyarakat umum serentak memberi dukungan dan respon positif untuk menjawab tantangan dan mewujudkan amanah yang diberikan kepada aparat Peradilan Agama (Mahkamah Agung RI, 2007;207)

Konsekwensi kewenangan di lingkungan Peradilan Agama yang telah menjadi satu atap di Departemen Kehakiman, maka Peradilan Agama harus menyiapkan sumber daya manusia (SDM) yang memadai dalam menghadapi kewenangan yang baru itu. Upaya dalam meningkatkan mutu agar dapat memenuhi tuntutan dalam bentuk meningkatkan pendalaman substansi pengetahuan yang telah ada maupun untuk mengisi dan meningkatkan pemahaman terhadap kompetensi baru.

Upaya dalam mempersiapkan sumber daya manusia tersebut baik dari segi fungsional maupun struktural harus diutamakan terhadap mutu kompetensinya khususnya untuk jabatan hakim, karena dalam asas ius curia novit, seorang hakim tidak boleh menolak perkara dengan alasan tidak menguasai hukumnya. Oleh karena itu seorang hakim dituntut untuk senantiasa aktif menambah wawasan dan pengetahuan hukum sesuai dengan perkembangan terbaru di lingkungan Peradilan Agama, terutama menguasai ilmu dan konsep dalam lingkup ekonomi syariah, sehingga dapat mewujudkan peradilan yang efektif dan efisien.

Apabila dalam kenyataannya Pengadilan Agama belum dapat menyelesaikan sengketa ekonomi syariah secara efektif, karena terdapat beberapa hambatan antara lain ketersediaannya sumber daya manusia yang kompeten dan memadai, sistem rekrutmen yang tidak efektif, serta belum lengkapnya peraturan mengenai hukum ekonomi syariah yang tembus dalam hukum acara yang berlaku di Peradilan Agama terutama dalam menyelesaikan sengketa ekonomi. Sementara sengketa ekonomi syariah merupakan sengketa bisnis yang menuntut penyelesaian sengketa dalam waktu yang singkat sehingga memerlukan hukum acara tersendiri yang lebih efektif dan efisien.

Bentuk lain yang kemungkinan masih bisa dilakukan dalam penyelesaian sengketa adalah dapat ditempuh selain melalui jalur litigasi yaitu penyelesaian sengketa ekonomi syariah melalui jalur non litigasi dengan menggunakan lembaga arbitrase dan dengan prosedur tetap seperti sebelum Undang-Undang No. 3 tahun 2006 
dengan syarat bahwa para pihak sepakat untuk menyelesaikan sengketa secara damai. Karena perbedaan yang paling mendasar dari penyelesaian sengketa ekonomi syariah antara sebelum dan setelah berlakunya Undang-Undang No. 3 tahun 2006 sesungguhnya ada pada keberadaan lembaga kekuasaan kehakiman yang dapat digunakan sebagai alternatif terakhir penyelesaian sengketa oleh para pihak jika para pihak tidak mencapai kesepakatan untuk menyelesaikan sengketa secara damai.

\section{DAFTAR PUSTAKA}

Abdul Manan, Penerapan Hukum Acara Perdata Di Lingkungan Peradilan Agama, Kencana Pranata, Jakarta.

Afdol, Kewenangan Pengadilan Agama Berdasarkan Undang Undang Nomor 3 Tahun 2006 dan Legislasi Hukum Islam Di Indnoesia, Airlangga University Press

Ahmad Dimyati. (1994). Badan Arbitrase Islam Di Indonesia, "Sejarah Lahirnya BAMUI, BAMUI Bekerjasama Dengan Bank Muamalat, Jakarta

Bagir Manan. (2006). Mediasi Sebagai Alternatif Menyelesaikan Sengketa, IKAHI, Jakarta

Hasnawati Abdullah. (2006). Penerapan Mediasi Di Dalam Praktek
Peradilan Agama, Forum Diskusi Hakim Pengadilan Agama Surabaya

Lailatul Arofah. (2004). Perdamaian Dan Bentuk Lembaga Damai Di Pengadilan Agama, Mimbar Hukum No. XV

M. Amin Rasyid. (2007). Teknis Penyelesaian Sengketa Bisnis Syariah Oleh Basyarnas, Yogyakarta

Muhamad Syafii Antonio. (2001). Bank Syariah Dari Teori Ke Praktek, Gema Insani Press Bekerjasama Dengan Tazkia Cendikia, Jakarta

Nasrudin Salim. (2004). Pemberdayaan Lembaga Damai Pada Pengadilan Agama, Mimbar Hukum No. 63 Tahun XV

Kumpulan Makalah Ekonomi Syariah. (2007). MARI, Direktorat Jenderal Badan Peradilan Agama, Jakarta,

Makalah Marni Mustafa. (2009). Mediasi dan Dading, Disampaikan Pada Pendidikan Hakim Peradilan Umum

Makalah, Takdir Rakmadi. (1996). Mekanisme Alternatif Penyelesaian Sengketa Lingkungan, Dalam Penataran Hukum Lingkungan Proyek Kerjasama Indonesia - Belanda Pada Fakultas Hukum Universitas Airlangga 


\section{PERATURAN PERUNDANG- UNDANGAN}

Undang Undang Nomor 3 Tahun 2006 Tentang Perubahan Atas undang Undang Nomor 7 Tahun 1989 Tentang Peradilan Agama.

Undang Undang Nomor 7 Tahun 1989 Tentang Peradilan Agama.

Undang Undang Nomor 30 Tahun 1999

Tentang Arbitrase Dan Alternatif

Penyelesaian Sengketa.

Undang Undang Nomor 4 Tahun 2004 Tentang Kekuasaan Kehakiman.

Undang Undang Nomor 8 Tahun 2004 Tentang Peradilan Umum.

Peraturan Dan Prosedure Penerapan Putusan Basyarnas. 